\title{
Pengaruh Partisipasi Anggota terhadap Kinerja KUD Di Kecamatan Tapung Kabupaten Kampar
}

\author{
RISMAN \\ Dosen tetap Sekolah Tinggi Ilmu Ekonomi Riau
}

\begin{abstract}
The issue of performance KUD in Kampar regency low because alleged by the participation of its members. Based on the results of studies using 93 respondents KUD members proves that the participation of members and not significant positive effect on the performance of cooperatives, it can be shown with the sig of 0.034 and the value of the effect of 0.008 . Value influence member participation, and not significant positive effect on the performance of KUD members. This means KUD is not yet a true KUD, where KUD good steward is to be memintarkan and prosper member, go look for life or property at KUD.
\end{abstract}

Keywords: KUD Performance, Member Participation

\section{PENDAHULUAN}

Badan usaha koperasi adalah suatu badan usaha yang dibentuk secara bersama-sama berdasarkan asas kekeluargaan. Pentingnya badan uaha koperasi ini karena koperasi sangat berperan dalam menumbuhkan dan mengembangkan potensi ekonomi rakyat serta dalam mewujudkan kehidupan demokrasi ekonomi yang didasari oleh kebersamaan, keterbukaan dan kekeluargaan. Sebagai lembaga yang bergerak di bidang pelayanan jasa keuangan, koperasi akan membantu melancarkan arus uang dari suatu tempat ketempat lain, melancarkan transaksi antara supply dan demand, melancarkan pengadaan modal investasi dan modal kerja bagi usaha-usaha yang tergolong prioritas maupun bukan prioritas, semua memerlukan jasa koperasi.

Dalam usaha memberikan pelayanan yang memuaskan bagi anggota, telah banyak koperasi yang bersaing menawarkan keunggulan-keunggulan produk atau jasanya yang dapat membuat konsumen tertarik dan percaya untuk menanamkan untuk bersama-sama membangun koprasi. Untuk memperoleh keunggulan daya saing dalam skala global, selain produk atau jasa koperasi dituntut pula untuk menyajikan atau memberikan pelayanan yang berkualitas. Kabupaten Kampar adalah salah satu daerah yang memiliki konsentrasi koperasi terbesar di Propinsi Riau, permasalahan umum koperasi di daerah ini adalah kinerja koperasi khususnya bila dilihat dari rapat anggota tahunan (RAT) yang diselenggarakan dalam rangka mempertanggungjawabkan kepengurusan pengurus kepada anggota yang telah memberikan kepercayaan kepada pengurus untuk mengelola koperasi.

perkembangan unit koperasi di Kabupaten Kampar mengalami fluktuasi, kemudian juga jumlah anggotanya. Selain itu juga dilihat dari volume usaha mengalami penurunan dan juga jumlah simpanan anggota yang cenderung menurun serta partisipasi anggota terhadap koperasi yang stabil. Berdasarkan hasil penelitian terdahulu terdapat banyak faktor yang mempengaruhi kinerja KUD, sebagaimana hasil penelitian Lilis Nurlina (2010) kinerja KUD dipengaruhi oleh partisipasi anggotanya. Kemudian menurut Siska Ismail, Yanti Saleh, Amelia Murtisari (2013) bahwa kinerja KUD dipengaruhi oleh kompetensi pengurus dan karyawan serta jasa koperasi. Selain itu menurut Made Antara, Anderson Guntur Komenaung (2007) kinerja KUD dipengaruhi oleh kompetensi pengurus dan karyawan serta partisipasi anggota. Menurut Kartib Bayu (2006) kinerja KUD dipengaruhi oleh kompetensi pengurus dan partisipasi anggota. 
Kemudian dilihat dari kondisi real di lapangan dapat dilihat variasi produk atau jasa koperasi yang diberikan kepada anggota koperasi juga bervariasi yang dapat diketahui bahwa jasa koperasi mulai dari warung serba ada, kemudian simpan pinjam, angkutan tandan buah segar (TBS), jasa klinik, listrik dan penjualan pupuk serta alat pertanian. Namun tidak semua koperasi menyediakan jasa tersebut. Selain itu juga dapat diketahui kondisi koperasi dilihat dari melaksanakan rapat anggota tahunan, kemudian pengalaman pengurus dan karyawan serta pendidikan formal dari pengurus dan pendidikan karyawan.

sebagian besar koperasi tidak aktif, kemudian pengurus kurang berpengalaman yang hanya 3 - 5 tahun, sedangkan karyawan merupakan karyawan yang sudah cukup berpengalaman yakni 5 - 10 tahun dan pedidikan rata-rata pengurus adalah SMA dan karyawannya juga SMA. Di Kabupaten Kampar terdapat 21 Kecamatan diantaranya tersebar sebanyak 475 unit koperasi yang aktif sebanyak 379 dan yang tidak aktif sebanyak 96 koperasi. Koperasi yang terdapat di Kecamatan Tapung yang berjumlah 52 unit koperasi di tahun 2013. Koperasi tersebut yang memiliki produk yang kompetitif sesuai dengan kebutuhan konsumen dan layanan yang prima.

Tingkat kepentingan konsumen terhadap jasa yang akan mereka terima dapat dibentuk berdasarkan pengalaman dan saran yang mereka peroleh. Konsumen memilih pemberi jasa berdasarkan peringkat kepentingan. Dan setelah menikmati jasa tersebut mereka cenderung akan membandingkannya dengan yang mereka harapkan. Bila jasa yang mereka nikmati ternyata berada jauh di bawah jasa yang mereka harapkan, para konsumen akan kehilangan minat terhadap pemberi jasa tersebut. Sebaliknya, jika jasa yang mereka nikmati memenuhi atau melebihi tingkat kepentingan, mereka akan cenderung memakai kembali produk jasa tersebut.

Permasalahan mengenai kepengurusan KUD menjadi perbincangan, dimana pengurus merupakan salah satu faktor yang mempengaruhi kinerja KUD, dimana selain itu juga anggota juga bagian lainnya. Permasalahan pengurus yang kurang kompeten dalam mengelola koperasi menjadia kendala. Selain itu pengurus kurang baik dalam memberikan pelayanan, sehingga ada kecenderungan partisipasi anggota terhadap koperasi juga ada kesan rendah. Selain itu dari sisi anggota masih dirasakan bahwa kesadaran anggota terhadap koperasi masih rendah karena kurangnya pengetahuan mengenai perkoperasian, dan juga pengurus kurang memberikan sosialisasi kepada anggota akan keberadaan koperasi tersebut.

Beberapa rujukan dalam penelitian ini Pengertian kinerja menurut Prawirosentono (2008: 1) performance atau Kinerja adalah hasil kerja yang dapat dicapai oleh seseorang atau sekelompok orang dalam suatu organisasi, sesuai dengan wewenang dan tanggung jawabnya masing-masing, dalam rangka upaya mencapai tujuan organisasi bersangkutan secara legal, tidak melanggar hukum dan sesuai dengan moral maupun etika. Kemudian menurut Tika (2005: 121) sebagai hasil fungsi pekerjaan/kegiatan seseorang atau kelompok dalam suatu organisasi yang dipengaruhi oleh berbagai faktor untuk mencapai tujuan organisasi dalam periode waktu tertentu. Mangkunegara (2009), mengemukakan bahwa Kinerja atau kinerja adalah hasil kerja secara kualitas dan kuantitas yang dicapai oleh seseorang karyawan dalam melaksanakan tugasnya sesuai dengan tanggung jawab yang diberikan kepadanya.

Pendapat ini sesuai dengan defenisi yang dikemukakan oleh Wahjosumidjo (2001), bahwa Kinerja adalah sumbangan secara kualitatif dan kuantitatif yang terukur dalam rangka membantu tercapainya tujuan kelompok dalam suatu unit kerja. Defenisi tersebut dapat ditafsirkan bahwa Kinerja merupakan kontribusi yang diberikan oleh pegawai baik ditinjau dari segi kualitas atau mutu kerja maupun dari segi jumlah yang dihasilkan dari pekerjaan tersebut, terukur dalam rangka membantu tercapainya tujuan suatu organisasi kerja. 
Menurut Robbin (1996), Kinerja adalah hasil tugas individual, perilaku dan ciri. Hasil tugas seperti jumlah yang dihasilkan, jumlah sumber daya yang digunakan, biaya perunit, volume penjualan, kenaikan penjualan, pertambahan rekening, perilaku seperti cara melayani, kepemimpinan, cuti sakit, kehadiran dan ciri seperti sikap yang baik, rasa percaya diri dan kooperatif. Dapat ditafsirkan bahwa Kinerja tidak hanya diukur dari hasil yang dicapai, tetapi juga segala tingkah laku seseorang dalam melaksanakan pekerjaan dan sikap yang ditunjukkan seseorang untuk mencapai sasaran pekerjaan. Sementara itu (Martoyo, 1998), mengemukakan bahwa Kinerja adalah hasil pencapaian pelaksanaan tugas-tugas yang dibebankan kepada setiap pekerja.

Berdasarkan pengertian-pengertian di atas maka dapat disimpulkan bahwa kinerja adalah merupakan hasil kerja keseluruhan pekerjaan secara kualitas dan kuantitas yang telah dilakukan seorang pegawai dalam mencapai apa yang menjadi tujuan organisasi. Manfaat kinerja menurut Prawirosentono dalam Sianipar dan Entang (2001: 5) bahwa pada prinsipnya kinerja unit-unit organisasi dimana seseorang atau sekelompok orang (group of human being) berada didalamnya merupakan pencerminan dari kinerja sumberdaya manusia yang bersangkutan. Dengan demikian pokok utama yang harus dinilai hasil kerjanya adalah unsur manusia, karena merekalah yang berperan didalamnya. Mereka merupakan sumber daya yang sangat berperan dalam menentukan kinerja organisasi. Kinerja dapat berupa produk akhir (barang dan jasa) dan atau berbentuk perilaku, kecakapan, kompensasi, sarana dan keterampilan spesifik yang dapat mendukung pencapaian tujuan dan sasaran organisasi.

Hal ini menurut Bacal (2001: 12) menjelaskan bahwa agar kinerja sesuai dengan yang dipersyaratkan maka perlu menerapkan manajemen kinerja yaitu komunikasi yang berlangsung terus menerus antara manajer dan setiap karyawan, untuk memperjelas tanggung jawab kerja serta meningkatkan kinerja secara berkesinambungan yakni melalui perencanaan kerja, komunikasi yang berlangsung terus menerus dan melakukan evaluasi melalui pengumpulan data dan pengamatan serta dokumentasi.

Lebih lanjut Siagian, (2008: 224) menyatakan penilaian Kinerja perlu dilakukan secara formal berdasarkan kriteria yang ditetapkan secara objektif serta didokumentasikan secara sistematik. Jadi penilaian Kinerja ini diperlukan untuk menentukan tingkat kontribusi individu. Penilaian terhadap kinerja organisasi yang dikemukakan oleh Menginson (1981: 310) yaitu suatu proses yang digunakan pimpinan untuk menentukan apakah karyawan melakukan pekerjaannya sesuai dengan tugas dan tanggungjawabnya. Ukurannya adalah skala likert yang mengukur sikap pegawai terhadap indikator berikut: Mutu pekerjaan; kejujuran; inisiatif; kehadiran; sikap; kerjasama; keandalan; pengetahuan tentang pekerjaan; tanggung jawab dan pemanfaatan waktu.

Mustopo (2000: 63) pengukuran kinerja dapat dijalankan dengan efektif dan efisien, perlu diperhatikan hal-hal berikut ini: Kondisi nyata dari organisasi; Latar belakang pemikiran; Aplikasi pengukuran kinerja; dan mengikuti perubahan. Arep (2003: 125) menyatakan bahwa melakukan penilaian terhadap kinerja pegawai adalah : 1) Atasan; 2) Karyawan itu sendiri; 3). Rekan sekerja. Kemudian Mc Menn dan Nanny (1994: 101), mengemukakan bahwa beberapa atribut yang diperlukan agar tercipta suatu sistem pengukuran kinerja yang efektif antara lain: Mendukung dan konsistensi dengan tujuan, tindakan, budaya dan faktor-faktor kunci keberhasilan organisasi; Relevan dan mendukung strategi; Digerakkan oleh pelanggan; Integral dengan seluruh fungsi dan organisasi; Mendorong kerjasama dalam organisasi baik secara horizontal maupun vertikal; Terhubung dengan aktivitas sehingga dapat dilihat hubungan yang jelas antara sebab dan akibat; Dapat dimanfaatkan untuk memberi realtime feedback; dan 
Mendukung bagi pembelajaran individu dan organisasi serta mendorong perbaikan secara kontinu.

Dimensi kinerja organisasi menurut Agus Dwiyanto (2002: 57) sebagai berikut :

a. Produktivitas, konsep produktifitas mengukur tingkat efisiensi dari penggunaan sumber daya dalam rangka menghasilkan hasil kerja yang optimal.

b. Kualitas layanan, Isu mengenai kualitas layanan cenderung menjadi semakin penting dalam menjelaskan kinerja organisasi pelayanan publik. Dilihat dari kepuasan dari pelanggan terhadap organisasi dalam memberikan jasanya.

c. Responsivitas, adalah kemampuan organisasi untuk mengenali kebutuhan masyarakat, menyusun agenda dan prioritas pelayanan dan mengembangkan program-program pelayanan publik sesuai dengan kebutuhan dan aspirasi pelanggan.

d. Responsibilitas yang menjelaskan apakah pelaksanaan kegiatan organisasi itu dilakukan sesuai dengan prinsip-prinsip administrasi yang benar atau sesuai dengan kebijakan organisasi, baik yang eksplisit mauupun implisit.

e. Akuntabilitas, akuntabilitas menunjuk pada seberapa besar kebijakan dan kegiatan organisasi tunduk pada para pengurus yang diangkat oleh anggota.

Berdasarkan uraian di atas, maka dapat disimpulkan bahwa kinerja KUD merupakan hasil kerja keseluruhan pekerjaan secara kualitas dan kuantitas yang telah dilakukan pengurus KUD dalam mencapai apa yang menjadi tujuan KUD. Dimensi Kinerja KUD adalah : 1) Produktivitas;

2) Kualitas layanan; 3) Responsivitas; 4) Responsibilitas; dan 5) Akuntabilitas. Faktor yang mempengaruhi kinerja, secara rinci dikemukakan oleh Mangkunegara (2002: 67) antara lain : (1) individu yang memiliki kemampuan, keterampilan mencakup mental dan fisik, latar belakang: keluarga, umur dan jenis kelamin, (2) organisasi meliputi : sumber daya, kepemimpinan, imbalan dan prosedur kerja, tim work dan (3) psikologi meliputi: persepsi, sikap, kepribadian dan motivasi serta komitmen. Lebih dari itu, adapun yang mempengaruhi faktor-faktor kinerja dalam suatu organisasi adalah faktor kemampuan dan faktor motivasi.

Menurut Tika (2010: 121) kinerja adalah hasil-hasil fungsi pekerjaan, faktor-faktor yang berpengaruh terhadap kinerja, pencapaian tujuan organisasi dan periode waktu. Kinerja ini dapat diukur dengan beberapa dimensi antara lain: Keterlibatan, yakni keterlibatan yang tinggi dari anggota-anggota organisasi berpengaruh terhadap kinerja perusahaan, nilai dan norma, tradisi merupakan konsensus bagi anggota organisasi untuk melibatkan diri dalam kegiatan-kagiatan organisasi; Konsistensi, yakni menyangkut masalah keyakinan, nilai, simbol dalam penerapannya untuk mencapai tujuan organisasi; Adaptabilitas, yakni penjabaran dari setiap orang yang terlibat dalam organisasi terhadap nilai dan norma yang berlaku dalam organisasi yang dilihat dari kemampuan untuk menyadari, beraksi ke dalam dan beraksi keluar; dan misi, yakni penghayatan misi dari organisasi dalam menentukan makna dan manfaat serta memberikan kejelasan arah organisasi yang akan dicapai.

Berdasarkan uraian di atas, maka dapat disimpulkan bahwa kinerja KUD dipengaruhi oleh banyak hal, antara lain dari faktor organisasi yakni kompetensi pengurus dan karyawan dan variasi produk yang ditawarkan. Selanjutnya dari faktor individu yakni partisipasi anggota.

\section{METODE}

Penelitian ini menggunakan metode kuantitatif, sampel penelitian ini adalah anggota koperasi dari 3 koperasi besar, menengah dan kecil sebanyak 93 orang yang diambil secara random sampling. Data dikumpulkan dengan angket dan dianalisis dengan metode regresi sederhana. 


\section{HASIL}

Kinerja KUD adalah merupakan hasil kerja keseluruhan pekerjaan secara kualitas dan kuantitas yang telah dilakukan poengurus KUD dalam mencapai apa yang menjadi tujuan KUD. Dimensi Kinerja KUD adalah: Produktivitas, konsep produktifitas mengukur tingkat efisiensi dari penggunaan sumber daya dalam rangka menghasilkan hasil kerja yang optimal; Kualitas layanan, Isu mengenai kualitas layanan cenderung menjadi semakin penting dalam menjelaskan kinerja organisasi pelayanan publik. Dilihat dari kepuasan dari pelanggan terhadap organisasi dalam memberikan jasanya; Responsivitas, adalah kemampuan organisasi untuk mengenali kebutuhan masyarakat, menyusun agenda dan prioritas pelayanan dan mengembangkan program-program pelayanan publik sesuai dengan kebutuhan dan aspirasi pelanggan; Responsibilitas yang menjelaskan apakah pelaksanaan kegiatan organisasi itu dilakukan sesuai dengan prinsip-prinsip administrasi yang benar atau sesuai dengan kebijakan organisasi, baik yang eksplisit maupun implisit; Akuntabilitas, akuntabilitas menunjuk pada seberapa besar kebijakan dan kegiatan organisasi tunduk pada para pengurus yang diangkat oleh anggota.

Partisipasi anggota merupakan salah satu cara untuk memotivasi yang mempunyai ciri khas yang lain daripada yang lain dalam rangka ikut dalam kegiatan KUD, dimensinya adalah: Turut memikirkan nasib sendiri dengan memanfaatkan KUD sebagai mitra; Kesadaran bermasyarakat dan bernegara yang tinggi dengan menyerahkan penentuan nasib kepada koperasi; Kewajiban sebagai warga negara yang bertanggung jawab dalam membayar simpanan dan kewajiban anggota; Ketaatan kepada berbagai peraturan yang telah ditetapkan dalam koperasi; Kerelaan melakukan pengorbanan yang dituntut KUD dalam pengembangan bersama ke depan.

Secara individual uji statistik yang digunakan adalah uji t pada tabel diperoleh nilai $\mathrm{t}(\mathrm{X})$ $=0.071$. Terlihat bahwa pada kolom signifikan pada tabel coefficients sub-struktur 2 didapat nilai sig 0,943. Nilai sig 0,943>0,05, maka Ho diterima, artinya partisipasi anggota tidak berpengaruh signifikan terhadap kinerja KUD. Hal ini disebabkan karena anggota merasa karyawan dan pengurus sudah kompeten dalam mengurusi koperasi sehingga menyebabkan anggota kurang berpartisipasi dalam melaksanakan pengawasannya menjalankan koperasi.

\section{PEMBAHASAN}

Berdasarkan hasil pengolahan data diketahui bahwa partisipasi anggota berpengaruh positif dan tidak signifikan terhadap kinerja KUD, hal ini dapat ditunjukkan dengan nilai sig sebesar 0,943 dan nilai pengaruh sebesar 0,008. Nilai pengaruh partisipasi anggota berpengaruh positif dan tidak signifikan terhadap kinerja KUD anggota ini berarti bahwa semakin tinggi partisipasi anggota maka semakin tinggi kinerja KUD. Pengaruhnya sebesar 0,008 satuan yang artinya apabila partisipasi meningkat satu satuan sedangkan variabel lain dalam hal ini adalah variabel kompetensi pengurus dan kompetensi karyawan dan variasi produk tetap maka kinerja KUD akan meningkat sebesar 0,008 satuan.

Berdasarkan hasil penelitian tentang partisipasi anggota merupakan salah satu cara untuk memotivasi yang mempunyai ciri khas yang lain daripada yang lain dalam rangka ikut dalam kegiatan KUD dimana anggota kadang turut memikirkan nasib sendiri dengan memanfaatkan KUD sebagai mitra. Juga ada sebagian yang memiliki kesadaran bermasyarakat dan bernegara yang tinggi dengan menyerahkan penentuan nasib kepada koperasi. Kewajiban sebagai warga negara yang bertanggung jawab dalam membayar simpanan dan kewajiban anggota cukup berjalan dan adanya ketaatan kepada berbagai peraturan yang telah ditetapkan dalam koperasi 
serta adanya kerelaan melakukan pengorbanan yang dituntut KUD dalam pengembangan bersama ke depan sehingga kinerja KUD membaik namun tidak nyata.

Hasil penelitian ini sejalan dengan penelitian Anggraini, Novi Hasti (2009) hasil penelitian menunjukkan bahwa jumlah anggota berpengaruh signifikan terhadap jumlah Sisa Hasil Usaha pada tingkat signifikansi 5\% sedangkan jumlah modal sendiri dan modal luar tidak berpengaruh secara signifikan pada tingkat $5 \%$.

\section{SIMPULAN}

Berdasarkan hasil penelitian maka dapat disimpulkan bahwa partisipasi anggota berpengaruh positif dan tidak signifikan terhadap kinerja KUD, hal ini dapat ditunjukkan dengan nilai sig sebesar 0,034 dan nilai pengaruh sebesar 0,008. Nilai pengaruh partisipasi anggota berpengaruh positif dan tidak signifikan terhadap kinerja KUD anggota. Ini berarti KUD yang dimaksud belum menjadi KUD yang sejati, dimana pengurus KUD yang baik adalah yang bisa memintarkan dan memakmurkan anggota, buka mencari kehidupan atau kekayaan di KUD.

\section{DAFTAR PUSTAKA}

Azis Slamet Wiyono, 2005, studi tentang kualitas pelayanan dan kepuasan konsumen dl rumah sakit islam manisrenggo klaten, Program Pascasarjana Universitas Muhammadiyah Surakarta.

Barata, Atep, Adya, 2004, Dasar-dasar Pelayanan Prima, (Persiapan Membangun Budaya Pelayanan Prima untuk Meningkatkan Kepuasan dan Loyalitas Pelanggan), Jakarta: Elex Media Komputindo.

Budiono, 2005, Pelayanan Prima Perpajakan, Rineka Cipta, Jakarta.

Cahyasumirat, Gunawan, 2006, pengaruh profesionalisme dan komitmen organisasi terhadap kinerja internal auditor, dengan kepuasan kerja sebagai variabel intervening (studi empiris pada internal auditor pt. Bank abc). Masters thesis, Program Pascasarjana Universitas Diponegoro.

Dwiyanto, Agus, 2005, Penilaian Kinerja Organiasi Publik, Yogyakarta : UGM

Gasperz, Vincent, 2007, Manajemen Bisnis Total dalam Era Globalisasi, PT. Gramedia Pustaka Utama, Jakarta.

Guntur Ujianto. 2005, Alumni Magister Manajemen Universitas Islam Indonesia, Kajian Bisnis dan manjemen. Analisis pengaruh komitmen profesional dan komitmen organisasional terhadap kepuasan kerja karyawan pada bank bukopin yogyakarta.

Hardman, 1994, Job Satisfaction Of Female Public Scholl Administration In West Virginia.

Jochen, Ropke. 2000, Ekonomi Koperasi Teori dan Manajemen. Salemba Empat, Jakarta.

Kotler, Philip, 2007, Manajemen Pemasaran: Analisa, Perencanaan dan control, Jilid I, Edisi Revisi, Erlangga, Jakarta 
Moenir, 2000, Manajemen Pelayanan Umum di Indonesia, Jakarta: Bumi Aksara.

Pamudji, 2008, Kepemimpinan Pemerintahan Indonesia, Jakarta: Bumi Aksara.

Pangabean, 2001, Manajemen Sumber Daya Manusia, Ghalia Indonesia, Bogor.

Purwanto, 2010, Administrasi dan Supervisi Pendidikan, PT. Remaja Rosdakarya, Bandung

Robbins, Sthepens, 2005, Perilaku Organisasi, Terjemahan Tim Indeks. Indeks - Garamedia, Jakarta.

Soewarso, Hardjosoedarmo, 2002, Total Quality Management, Andi Offset, Yogyakarta.

Wahyudi, 2009, Meningkatkan Kinerja BUMN: Antisipasi Terhadap Kompetensi dan Deregulasi, Yogyakarta: JKAP No1 